\title{
PIDANA PEMISKINAN KORUPTOR PADA TINDAK PIDANA KORUPSI \\ BERDASARKAN UNDANG-UNDANG PEMBERANTASAN \\ TINDAK PIDANA KORUPSI
}

\author{
Agus Sugiarto, \\ Universitas Nahdlatul Ulama Cirebon \\ Email : sugiartoagus2020@gmail.com
}

\begin{abstract}
Corruption is a large and interesting problem as a legal matter concerning complicated crime types. It contains multiple aspects of economic relations, politics, social, and culture. Various efforts to eradicate corruption have been done. However, in terms of quantity and quality of the perpetrators the corruption is still increasing. It is necessary to prevent and reduce the occurrence of corruption cases. One of the discourses to tackle corruption in Indonesia is the impoverishment of corruptors. The research objective is to analyze the problems that have been formulated. The research method used is normative juridical with qualitative analysis. The results of the research and discussion of the thesis states that 1) the regulation of impoverishment of criminals against corruptors as one of the alternative sentences in corruption in Indonesia has not been explicitly regulated in legislation to eradicate corruption; 2) the obstacles faced in the application of criminal impoverishment or payment of compensation money for state financial losses of corruptors is difficult. It is difficult to find wealth owned by corruptors, either because it is hidden by means of naming other names, or indeed the convicted of corruption does not have any wealth.
\end{abstract}

\section{Keywords: Criminal, Impoverishment, Crime, Corruption Eradication}

\section{PENDAHULUAN}

Korupsi merupakan masalah yang yang besar dan menarik sebagai persoalan hukum yang menyangkut jenis kejahatan yang rumit penanggulangannya, karena korupsi mengandung aspek yang majemuk dalam kaitannya dengan politik, ekonomi, sosial dan budaya. Berbagai upaya pemberantasan telah dilakukan, namun tidak mampu memberantas kejahatan korupsi, bahkan semakin lama semakin meningkat baik segi kualitas pelakunya sehingga perlu dilakukan upaya pencegahan dan mengurangi terjadinya kasus korupsi. Korupsi sudah berkembang dilingkungan eksekutif, legislatif, dan yudikatif. Hal ini jelas sangat merugikan perekonomian negara Indonesia. Salah satu tindak pidana yang selalu menjadi sorotan di Indonesia adalah masalah korupsi. Korupsi bukanlah hal yang asing lagi di negeri ini. Korupsi di Indonesia bahkan sudah tergolong extra-ordinary crime atau kejahatan luar biasa karena telah merusak, tidak saja keuangan Negara dan potensi 
ekonomi Negara, tetapi juga telah meluluhkan pilar-pilar sosio budaya, moral, politik, dan tatanan hukum keamanan nasional ${ }^{1}$.

Konsekuensi logis bahwa korupsi merupakan extra ordinary crime, diperlukan penanggulangan dari aspek yuridis yang luar biasa dan perangkat hukum yang luar biasa pula. Cara cara konvensional terbukti sampai saat in belum mampu memberantas tindak pidana korupsi, bahkan kecenderungan semakin hari semakin canggih, baik dari modus operandinya maupun dari jumlah kekayaan negara yang dikorupsi. Indonesia sebenarnya telah memiliki peraturan mengenai pemberantasan tindak pidana korupsi sejak tahun 1971, yaitu Undang-undang (UU) Nomor 3 Tahun 1971 tentang Pemberantasan Tindak Pidana Korupsi. Namun karena peraturan ini dianggap sudah tidak mampu lagi mengikuti perkembangan kebutuhan hukum dalam masyarakat maka terbitlah UU Nomor 31 Tahun 1999 tentang Pemberantasan Tindak Pidana Korupsi, yang kemudian direvisi melalui UU Nomor 20 Tahun 2001 pada beberapa pasalnya ${ }^{2}$.

Korupsi tidak hanya dilakukan oleh pejabat pemerintahan akan tetapi dilakukan oleh pengusaha dan pihak pihak yang terkait baik di tingkat pusat maupun di tingkat daerah. Undang-undang Nomor 31 Tahun 1999 tentang Pemberantasan Tindak Pidana Korupsi sebagaimana telah diubah dan ditambah dengan Undang-undang Nomor 20 Tahun 2001 tentang Perubahan Atas Undang-undang Nomor 31 Tahun 1999 tentang Pemberantasan Tindak Pidana Korupsi.

Undang-undang Pemberantas Tindak Pidana Korupsi memiliki sanksi pidana yang penerapannya dilakukan secara kumulatif sanksi dalam Undang-undang terkait tindak pidana korupsi belum mampu mengurangi tindak pidana korupsi. Sangat diperlukan terobosan baru dan tindakan konkret untuk mengatasi korupsi. Belakangan ini ada acara alternatif yang diwacanakan oleh para pengamat hukum supaya aparat penegak hukum menggunakan sanksi pemiskinan koruptor. Kasus korupsi sudah menjadi masalah yang menghambat pembangunan nasional. Korupsi juga dapat melemahkan sendi-sendi kehidupan di dalam masyarakat, bangsa, dan negara. Dengan meningkatnya jumlah koruptor dari tahun ke tahun maka penulis tertarik untuk meneliti bagaimana konsep pemikiran dan dasar hukum permiskinan koruptor sebagai salah satu hukuman alternatif

\footnotetext{
1 Ermansjah Djaja, Memberantas Korupsi Bersama KPK (Komisi Pemberantasan Korupsi), Sinar Grafika, Jakarta, 2010, hlm. 13.

2 Undang-Undang Nomor 20 Tahun 2001 tentang perubahan atas Undang-Undang Nomor 31 Tahun 1999 tentang Pemberantasan Tindak Pidana Korupsi.
} 
dalam tindak pidana korupsi dan bagaimana implementasi sanksi pidana pemiskinan koruptor di Indonesia.

Dapat ditegaskan bahwa korupsi itu selalu bermula dan berkembang di sektor pemerintahan (publik) dan perusahaan-perusahaan milik negara. Dengan bukti-bukti yang nyata dengan kekuasaan itulah pejabat publik dan perusahaan milik negara dapat menekan atau memeras para orang-orang yang memerlukan jasa pelayanan dari pemerintah maupun Badan Usaha Milik Negara (BUMN) ${ }^{3}$.

Dari uraian diatas penulis merumuskan penelitian dengan judul: PIDANA

\section{PEMISKINAN KORUPTOR PADA TINDAK PIDANA KORUPSI BERDASARKAN UNDANG UNDANG PEMBERANTASAN TINDAK PIDANA KORUPSI.}

Berdasarkan latar belakang permasalahan diatas maka penulis mengangkat permasalahan yang akan di teliti sebagai berikut:

1. Bagaimanakah peraturan pidana pemiskinan terhadap koruptor sebagai salah satu hukuman alternatif dalam tindak pidana korupsi di Indonesia?

2. Apakah kendala yang dihadapi dalam penerapan pidana pemiskinan terhadap pelaku korupsi?

\section{METODE}

Dalam penelitian hukum ini, penulis menggunakan pendekatan penelitian hukum normatif yang bersifat eksploratoris dan deskriptif, diarahkan untuk menganalisis data sekunder. Penelitian ini dititikberatkan pada studi kepustakaan dengan acuan pada terori murni Hans Kelsen, pendekatan semacam itu penting guna menghindari pencampuran metodologi antara disiplin disiplin yang berlainan yang dapat mengaburkan intisari ilmu pengetahuan hukum dan melenyapkan batasan-batasan dari hakikat objek studinya itu, dalam penelitian ini diterapkan sistem analisis utama secara yuridis normatif, sedangkan secara sosiologis merupakan penunjang. Penelitian deskriptif adalah jika penelitian bertujuan untuk menggambarkan secara cermat karakteristik dari fakta-fakta dan untuk menentukan frekuensi sesuatu yang terjadi. Penelitian ini dimaksudkan untuk memberikan deskripsi yang seteliti mungkin tentang sesuatu objek penelitian.

\footnotetext{
${ }^{3}$ Romli Atmasasmita, Sekitar Korupsi Aspek Nasional dan Aspek Internasional, CV. Mandar Maju, Bandung, 2004, hlm. 1.
} 
Studi kepustakaan dilakukan untuk memperoleh data yang dianggap relevan untuk dijadikan bahan, dengan menggunakan dasar penelitian kepustakaan yang terdiri dari sumber hukum sekunder, primer dan tersier. Teknik analisis untuk memecahkan permasalahan dilakukan melalui analisis kualitatif untuk dapat menarik suatu kesimpulan yang dapat dipertanggung jawabkan secara ilmiah.

\section{HASIL DAN PEMBAHASAN}

\subsection{Tindak Pidana Korupsi}

Menurut Fockema Andreae, kata Korupsi berawal dari bahasa latin corruptio atau corruptus. Corruptio berasal dari kata corrumpere, suatu kata latin yang lebih tua. Dari bahasa latin itulah turun ke banyak bahasa Eropa seperti Inggris yaitu corruption, corrupt; Prancis yaitu corruption; dan Belanda yaitu corruptie, korruptie. Dari Bahasa Belanda inilah kata itu turun ke Bahasa Indonesia yaitu korupsi ${ }^{4}$. Ada beberapa pengertian kata korupsi, diantaranya adalah kebusukan, keburukan, kebejatan, ketidakjujuran, dapat disuap, tidak bermoral, penyimpangan dari kesucian, kata-kata atau ucapan yang menghina atau memfitnah. Pelaku korupsi pada umumnya menyalahgunakan kekuasaan atau jabatannya untuk kepentingan pribadi. Korupsi dikategorikan sebagai kejahatan kerah putih (white collar crime) mengingat pelaku korupsi yang mempunyai status sosial dan kedudukan yang terhormat.

Dalam Black's Law Dictionary, korupsi adalah perbuatan yang dilakukan dengan maksud untuk memberikan suatu keuntungan yang tidak resmi dengan hak-hak dari pihak lain secara salah menggunakan jabatannya atau karakternya untuk mendapatkan suatu keuntungan untuk dirinya sendiri atau orang lain, berlawanan dengan kewajibannya dan hak-hak dari pihak lain ${ }^{5}$.

Pengaturan hukum formal dan materiil tentang pemberantasan tindak pidana korupsi termasuk kolusi dan nepotisme telah cukup lengkap bagi aparat penegak hukum untuk melakukan penindakan terhadap pelaku korupsi khususnya, namun lemahnya konsistensi penerapan sistem hukum dalam penegakan hukum pemberantasan korupsi membuat masyarakat semakin skeptis. Rumusan delik korupsi di dalam Undang-undang Nomor 31 Tahun 1997 sebagian besar mengambil delik korupsi dari Undang-undang

\footnotetext{
${ }^{4}$ Andi Hamzah, Pemberantasan Korupsi Melalui Hukum Pidana Nasional dan Internasional, PT. Raja Grafindo Persada, Jakarta, 2006, hlm. 4.

${ }^{5}$ Chaerudin DKK, Strategi Pencegahan dan Penegakan Hukum Tindak Pidana Korupsi, PT Refika Aditama, Bandung, 2008, hlm. 2.
} 
Nomor 3 Tahun 1971, namun memperluas beberapa hal, antara lain : memperluas subyek tindak pidana korupsi: memperluas pengertian pegawai negeri: memperluas pengertian tindak pidana korupsi: memperluas jangkauan berbagai modus operandi keuangan negara dimana tindak pidana korupsi dirumuskan secara tegas berbagai tindak pidana formil; subyek korporasi dikenakan sanksi.

\subsection{Sejarah Pemberantasan Korupsi di Indonesia}

Pemberantasan tindak pidana korupsi telahlama dilaksanakan, namun tidaklah semudah membalikkan telapak tangan. Korupsi yang melibatkan para penguasa ini sangat sukar untuk di berantas. Singkatnya, "sejarah dan pemberantasan korupsi di Indonesia ${ }^{6 "}$ dapat dirangkum sebagai berikut:

- Tahun 1957, Operasi Militer, dasar hukumnya PRT/PM/06/1957. (Kegiatan tidak terstruktur)

- Tahun 1967, Tim Pemberantasan Korupsi, dasar hukumnya Keppres 228 Tahun 1967. (Represif dan Preventif)

- Tahun 1977, Opstib, dasar hukumnya, Inpres 9 Tahun 1977. (Penertiban Sistem \& Operasional)

- Tahun 1987, Pemsus Restitusi Pajak, dasar hukumnya Surat MENKEU S 1234 /MK.04/1987. (Kebenaran restitusi)

- Tahun 1997-1998 $\rightarrow$ Krisis Moneter \& Ekonomi

- Tahun 1999, KPKPN, dasar hukumnya UU 28 Tahun 1999. (Preventif) Tahun 1999, TGTPK, dasar hukumnya PP No. 19 Tahun 2000. (Represif).

- Tahun 2003, KPK, bertugas Koordinasi, Supervisi, Penindakan, Pencegahan, Monitoring, dasar hukumnya UU 30 Tahun 2002. (Penindakan \& Pencegahan).

- Tahun 2005, Timtas, bertugas Koordinasi diantara Kejaksaan, POLRI \& BPKP, dasar hukumnya Keppres 11 Tahun 2005. (Represif).

Berdasarkan rangkuman dari pemberantasan tindak pidana korupsi di Indonesia yang dijelaskan diatas, bahwa pemerintah Republik Indonesia benar-benar serius dalam melaksanakan pemberantasan tindak pidana korupsi yang merupakan kejahatan yang terorganisir, hampir menyamai kejahatan kemanusiaan yang dilaksanakan sejak era orde lama hingga reformasi.

\footnotetext{
${ }^{6}$ Busyro Muqoddas, Strategi Pemberantasan Korupsi KPK, Paper pada IP Seminar: Korupsi yang
} memiskinkan Jakarta, Tanggal 21-22 Februari, hlm. 55. 
Secara umum strategi pemberantasan korupsi di Indonesia dapat dibagi menjadi tiga, yakni:

1) Strategi preventif, yaitu strategi yang bersifat mencegah atau meminimalkan terjadinya tindak pidana korupsi.

2) Strategi detektif, yaitu strategi yang dimaksudkan untuk mengidentifikasi atau mendeteksi apakah telah terjadi tindak pidana korupsi sehingga apabila terdapat indikasi dapat segera diketahui secara akurat.

3) Strategi advokasi, yaitu strategi yang dilakukan dengan membangun sistem yang dapat menyelesaikan kasus-kasus korupsi secara umum dan memberikan sanksi yang setimpal dengan kejahatan korupsi yang dilakukan ${ }^{7}$.

\subsection{Teori Pemidanaan Pelaku Korupsi}

a) Teori Absolute atau vergeldings (Imbalan)

Menurut Satochid Kartanegara dan pendapat-pendapat para ahli hukum terkemuka dalam hukum pidana, mengemukakan teori pemidanaan atau penghukuman dalam hukum pidana dikenal ada tiga aliran yaitu: ${ }^{8}$

\section{Absolute atau vergeldings theorieen (vergelden/imbalan)}

Teori ini memberikan statement bahwa penjatuhan pidana semata-mata karena seseorang telah melakukan suatu kejahatan atau tindak pidana. Pidana merupakan akibat mutlak yang harus ada sebagai suatu pembalasan kepada orang yang telah melakukan kejahatan. Adapun yang menjadi dasar pembenarannya dari penjatuhan pidana itu terletak pada adanya kejahatan itu sendiri, oleh karena itu pidana mempunyai fungsi untuk menghilangkan kejahatan tersebut.

Teori absolut atau teori pembalasan dapat disimpulkan merupakan suatu bentuk pembalasan yang diberikan oleh negara yang bertujuan untuk memberikan penderitaan kepada para penjahat sebagai akibat perbuatannya. Hal ini bertujuan agar pemidanaan dapat menjadi balasan yang dapat dipandang oleh masyarakat umum sebagai hukuman yang setimpal dan dapat menimbulkan rasa puas bagi orang secara umum, dengan pemberlakuan pidana yang setimpal dengan perbuatan yang telah dilakukan. Sedangkan teori gabungan adalah teori yang yang menitikberatkan unsur pembalasan, teori gabungan yang menitikberatkan pertahanan tertib masyarakat, dan yang memposisikan seimbang antara pembalasan dan pertahanan tertib masyarakat.

\footnotetext{
${ }^{7}$ https://acch.kpk.go.id/.

${ }^{8}$ Satochid Kartanegara, Hukum Pidana Bagian Satu, Balai Lektur Mahasiswa, Jakarta, hlm. 56.
} 
b) Teori Relative atau Doel theorieen doe (Maksud dan Tujuan)

Relative atau doel theorieen doe (maksud dan tujuan) Menurut teori ini penjatuhan pidana bukanlah sekedar untuk melakukan pembalasan atau pengimbalan. Pembalasan itu sendiri tidak mempunyai nilai tetapi hanya sebagai sarana melindungi kepentingan masyarakat. Lebih lanjut teori ini menjelaskan bahwa tujuan dari penjatuhan pidana adalah sebagai berikut: a. Teori menakutkan yaitu tujuan dari pidana itu adalah untuk menakutnakuti seseorang, sehingga tidak melakukan tindak pidana baik terhadap pelaku itu sendiri maupun terhadap masyarakat (preventif umum). b. Teori memperbaiki yaitu bahwa dengan menjatuhkan pidana akan mendidik para pelaku tindak pidana sehingga menjadi orang yang baik dalam masyarakat (preventif khusus). Sedangkan prevensi khusus, dimaksudkan bahwa pidana adalah pembaharuan yang esensi dari pidana itu sendiri. Sedangkan fungsi perlindungan dalam teori memperbaiki dapat berupa pidana pencabutan kebebasan selama beberapa waktu. Dengan demikian masyarakat akan terhindar dari kejahatan yang akan terjadi. Oleh karena itu pemidanaan harus memberikan pendidikan dan bekal untuk tujuan kemasyarakatan.

\subsection{Pemiskinan Bagi Koruptor}

Upaya pemiskinan koruptor ini sebenarnya sudah dimungkinkan dalam perUUan saat ini. Setidaknya harapan untuk melakukan pemiskinan terhadap pelaku korupsi dapat dilakukan melalui Undang-undang Nomor 8 Tahun 2010 tentang pencegahan dan pemberantasan tindak pidana pencucian uang (TPPU) dan pada pasal 18 UU Nomor 31 Tahun 1999 tentang pemberantasan tindak pidana korupsi yang berisikan pidana tambahan yang dapat dijatuhkan kepada pelaku korupsi.

Undang-undang TPPU memberikan dua terobosan hukum yang bisa digunakan oleh penegak hukum untuk memberantas dan memberikan efek jera kepada koruptor. Wakil Kepala PPATK, Agus Santoso ${ }^{9}$, mengungkapkan kedua terobosan itu yakni penuntutan kumulatif dan pembuktian terbalik atas harta kekayaan terdakwa. UU TPPU memberikan landasan hukum bagi penyidik untuk menggabungkan penyidikan tindak pidana asal, dalam hal ini tipikor, dengan penyidikan TPPU untuk kemudian dilanjutkan dengan penuntutan dakwaan kumulatif.

\footnotetext{
9 Setiawan, Aries, dan Ismoko Widjaya. PPATK: Ada Dua Terobosan Memberantas Korupsi. 28 September 2012. http://nasional.news.viva.co.id/news/read/354929ppatk-ada-duaterobosan-memberantas-korup, diakses pada 20 Januari 2020.
} 
Hasil penelitian dan pembahasan mengemukakan : 1) Pengaturan pidana pemiskinan terhadap koruptor sebagai salah satu hukuman alternatif dalam tindak pidana korupsi di Indonesia belum diatur secara tegas di dalam peraturan perundang-undangan pemberantasan tindak pidana korupsi 2) Kendala yang dihadapi dalam penerapan pidana pemiskinan atau pembayaran uang pengganti atas kerugian negara pelaku korupsi adalah sulit ditemukannya kekayaan yang dimiliki oleh koruptor, baik karena disembunyikan dengan mengatas namakan nama lain atau memang terpidana korupsi tidak memiliki kekayaan. Sebagai rekomendasi dikemukakan saran : 1) Hendaknya istilah pidana pemiskinan koruptor tidak diterapkan dalam Undang-undang pemberantasan korupsi di Indonesia karena bertentangan dengan HAM dan Hukum Islam 2) Hendaknya Perubahan Undang-undang Pemberantasan Korupsi yang akan dating mengatur tentang ketentuan "Gelang Koruptor" yang kenakan oleh koruptor yang tidak mampu membayar uang pengganti kerugian keuangan negara maupun denda, dan uang pengganti tidak dapat diganti dengan pidana kurungan dan gerakan revolusi mental yang telah dicanangkan, hendaknya para pemimpin negeri ini memberikan contoh dan teladan tentang akhlak dan moral yang baik, bukan memberikan contoh dengan semakin banyaknya para pemimpin negeri ini yang melakukan korupsi.

Tindak pidana korupsi menurut Undang-undang Nomor 31 Tahun 1999 dibagi dalam 2 (dua) kelompok besar, yaitu kelompok pertama, Bab II tentang tindak pidana korupsi terdiri dari pasal 2 sampai dengan pasal 20 dan kelompok ke dua, Bab III tentang Tindak Pidana lain yang berkaitan dengan Tindak Pidana Korupsi, definisi umum tentang korupsi tidak diberikan oleh Undang-undang ini. Perumusan tindak pidana korupsi menutur pasal 2 ayat 1 Undang-undang Nomor 31 tahun 1999 adalah setiap orang (orang perorangan atau korporasi) yang memenuhi unsur/elemen dari pasal tersebut.

Korupsi bukan hanya masalah Indonesia, tetapi sudah menjadi masalah seluruh bangsa. Oleh sebab itu lahirlah United Nation Convention Againts Corruption (UNCAC) dimana Indonesia sudah meratifikasi dengan UU No 7 Tahun 2006. Beberapa pengertian Korupsi menurut UNCAC itu antara lain adalah : (a) Penyuapan, janji, tawaran atau pemberian kepada pejabat, public/swasta/internasional, secara langsung atau tidak langsung, manfaat yang tidak semestinya untuk pejabat itu sendiri atau orang atau badan lain yang ditujukan agar pejabat itu bertindak atau berhenti bertindak dalam pelaksanaan tugas-tugas resmi mereka untuk untuk memperoleh keuntungan dari tindakan tersebut; (b) 
Penggelapan, penyalahgunaan atau penyimpangan lain oleh pejabat public/swasta/internasional; (c) Memperkaya diri sendiri dengan tidak sah. Korupsi merupakan tindakan jahat yang sangat berbahaya sehingga mesti ditanggulangi dengan kebijakan criminal. Korupsi tidak hanya merugikan keuangan negara, tetapi juga merupakan pelanggaran atas hak-hak sosial dan ekonomi masyarakat secara luas sehingga digolongkan sebagai kejahatan yang pemberantasannya dilakukan secara luar biasa. Bagaimana Criminal Policy atas tindak pidana korupsi. Dasar pemikiran munculnya wacana pemiskinan koruptor tidak lain adalah pertama, karena para koruptor seperti tidak jera dan makin tahun berjalan justru jumlah koruptor tampak tidak kunjung berkurang. Kedua, pidana yang ada berupa penjara, denda, dan kewajiban membayar uang pengganti dinilai kurang memberikan efek jera. Ketiga, keunikan perilaku korupsi. Keempat wacana pemiskinan koruptor dipicu oleh banyaknya vonis hakim yang rendah bagi koruptor. Pemiskinan koruptor merupakan langkah dan terobosan baru dalam memberantas korupsi. Banyak terdakwa kasus korupsi masih dapat menikmati banyak fasilitas, meskipun telah berstatus sebagai narapidana. Ketika pidana penjara sudah dirasakan tidak efektif dan tidak menjerakan koruptor, perlu terobosan baru dan tindakan konkret. Sanksi pidana pemiskinan koruptor dirasa perlu diterapkan dalam beberapa kasus korupsi dengan harapan dapat menimbukan efek jera bagi pelaku tindak pidana korupsi.

\section{PENUTUP}

\subsection{Simpulan}

Dari uraian diatas maka maka terdapat beberapa kesimpulan antara lain sebagai berikut:

1. Pengaturan pidana pemiskinan terhadap koruptor sebagai salah-satu hukuman alternatif dalam tindak pidana korupsi di Indonesia belum diatur secara tegas di dalam peraturan perundang-undangan pemberantasan tindak pidana korupsi, dimana jaksa penuntut umum dapat meyita dan melelang harta milik koruptor yang berasal dari korupsi untuk sebagai pengganti kerugian uang negara. Pada implementasinya isitilah pemiskinan justru digunakan oleh koruptor itu sendiri untuk lepas dari kewajiban mengganti kerugian negara, dengan cara membuat surat miskin dari pejabat berwenang seperti desa/lurah dan camat.

2. Kendala yang dihadapi dalam penerapan pidana pemiskinan atau pembayaran uang pengganti atas kerugian keuangan negara pelaku korupsi adalah sulit ditemukannya 
kekayaan yang dimiliki oleh koruptor, baik karena disembunyikan dengan mengatasnamakan nama lain atau memang tidak memiliki kekayaan dan syarat adanya surat miskin terpidana korupsi yang dikeluarkan oleh pejabat yang berwenang juga menjadi kendala untuk mengembalikan kerugian keuangan negara, dan menjadi peluang bagi koruptor untuk menyembunyikan hasil korupsi.

\subsection{Saran}

Memperhatikan hasil simpulan di atas, dapat dikemukakan beberapa saran sebagai berikut :

1. Hendaknya istilah pidana pemiskinan koruptor tidak diterapkan dalam Undangundang pemberantasan korupsi di Indonesia karena bertentangan dengan HAM dan Hukum Islam

2. Hendaknya Perubahan Undang-undang Pemberantasan Korupsi yang akan dating mengatur tentang ketentuan "Gelang Koruptor" yang kenakan oleh koruptor yang tidak mampu membayar uang pengganti kerugian keuangan negara maupun denda, dan uang pengganti tidak dapat diganti dengan pidana kurungan dan gerakan revolusi mental yang telah dicanangkan, hendaknya para pemimpin negeri ini memberikan contoh dan teladan tentang akhlak dan moral yang baik, bukan memberikan contoh dengan semakin banyaknya para pemimpin negeri ini yang melakukan korupsi.

\section{DAFTAR PUSTAKA}

\section{A. Buku}

Andi Hamzah, Pemberantasan Korupsi Melalui Hukum Pidana Nasional dan Internasional, PT. Raja Grafindo Persada, Jakarta, 2006

Chaerudin DKK, Strategi Pencegahan dan Penegakan Hukum Tindak Pidana Korupsi, PT Refika Aditama, Bandung, 2008

Ermansjah Djaja, Memberantas Korupsi Bersama KPK (Komisi Pemberantasan Korupsi), Sinar Grafika, Jakarta, 2010,

Romli Atmasasmita, Sekitar Korupsi Aspek Nasional dan Aspek Internasional, CV. Mandar Maju, Bandung, 2004

Satochid Kartanegara, Hukum Pidana Bagian Satu, Balai Lektur Mahasiswa, Jakarta. 


\section{B. Peraturan Perundang-Undangan}

Undang-Undang Nomor 20 Tahun 2001 tentang perubahan atas Undang-Undang Nomor 31 Tahun 1999 tentang Pemberantasan Tindak Pidana Korupsi.

\section{Sumber Lain}

Busyro Muqoddas, "Strategi Pemberantasan Korupsi KPK", Paper pada IP Seminar: Korupsi yang memiskinkan Jakarta, Tanggal 21-22 Februari, hlm. 55.

https://acch.kpk.go.id/

Setiawan, Aries, dan Ismoko Widjaya. PPATK: Ada Dua Terobosan Memberantas Korupsi. 28 September 2012. http:/ / nasional.news.viva.co.id/news/read/35 4929ppatk-ada-duaterobosan-memberantas-korup, diakses pada 20 Januari 2020. 